\title{
Hepatitis B virus surface antigen as a reporter of promoter activity
}

(Recombinant DNA; transient expression system; radioimmunoassay; Epstein-Barr virus regulation; immediate early promoters)

\author{
Manfred Marschall, Manfred Motz, Ulrike Leser, Fritz Schwarzmann, Barbara Oker and Hans Wolf \\ Max von Pettenkofer-Institute, University of Munich, D-8000 Munich (F.R.G.)
}

Received by W.C. Summers: 20 January 1989

Accepted: 30 March 1989

\section{SUMMARY}

The coding sequence for the hepatitis B virus surface antigen ( $\mathrm{HBsAg}$ ) was used as a new reporter gene for studies on eukaryotic promoter activity and upstream regulatory sequences. The data observed in transfection assays were comparable to results obtained with conventional chloramphenicol acetyltransferase (CAT) assays, as was demonstrated using various transcriptional regulation sequences. The expression of $\mathrm{HBs} \mathrm{Ag}$ as a reporter protein offered some advantages:

(i) In transient expression assays, a time course of promoter activity depending on variable culture conditions could be monitored over a period of time, since the HBsAg was secreted into the culture supernatant.

(ii) Evaluation of HBsAg from supernatant aliquots and quantification of the corresponding promoter activities could be performed easily, using the very sensitive and readily available diagnostic HBsAg kits.

(iii) In contrast to the conventional CAT assay, the cells remained available for further tests, e.g., Western blot, immunofluorescence or transcript analysis.

Characteristics of several Epstein-Barr virus (EBV) promoters, depending on the virus state of EBV-positive B-cells (latency, chemical induction, lytic superinfection, trans-activation), were assayed using the $\mathrm{HBsAg}$ reporter system.

Correspondence to: Prof. Dr. H. Wolf, Max von Pettenkofer-Institute, Pettenkoferstr. 9a, 8000 Munich 2 (F.R.G.)

Tel. (089)51605263; Fax (089) 5380584

Abbreviations: Ap, ampicillin; bp, base pair(s); CAT, Cm acetyltransferase; cat, gene encoding CAT; $\mathrm{Cm}$, chloramphenicol; cpm, counts per minute; DEAE, diethylaminoethyl; dpt, days post-transfection; EBV, Epstein-Barr virus; HBsAg, HBV surface antigen; HBV, hepatitis B virus; $k b$, standard kilobase(s) or
$1000 \mathrm{bp}$; lacPO, lac promoter-operator; LB, Luria-Bertani (mcdium); LMP, latent membrane protein; ORF, open reading frame; ori, origin of replication; $\mathrm{PBS}$, phosphate-buffered saline (150 mM NaCl$/ 100 \mathrm{mM} \mathrm{Na} \mathrm{Na}_{2} \mathrm{HPO}_{4} \cdot \mathrm{H}_{2} \mathrm{O}$ pH 7.2); Pollk, Klenow (large) fragment of $E$. coli DNA polymerase I; RIA, radioimmunoassay; RPMI, Roswell Park Memorial Institute; ${ }^{\mathbf{R}}$, resistance; SV40, simian virus 40; TPA, tumor promoting agent (phorbol-12-myristate-13-acetate); TTBS, $154 \mathrm{mM} \mathrm{NaCl} / 10 \mathrm{~mm}$ Tris pH 7.5/0.5\% Tween 20; UWGCG, Univ. of Wisconsin Genetics Computer Group. 


\section{INTRODUCTION}

Studies on activity and function of eukaryotic promoter sequences and upstream regulatory signals have been carried out using the DNA regions encoding CAT, $\beta$-galactosidase, alkaline phosphatase or luciferase as reporter genes (An et al., 1982; Gorman et al., 1982; deWet et al., 1982; Yoon et al., 1988 ), by correlating their expression with promoter activities.

We established a new reporter system using $\mathrm{HBsAg}$ as the reporter protein, which is secreted into the culture supernatant. The HBsAg is found in three variants of viral particles depending on the translational start on the HBV genome. Two larger forms containing pre-S sequences are found in minor quantities, whereas the smallest HBsAg is the predominant component. The HBsAg can be integrated into cellular membranes and secreted as $22-\mathrm{nm}$ particles into the culture supernatant (Michel et al., 1984). Using the HBsAg reporter system, kinetics of promoter activities could easily be analyzed under a variety of in vitro conditions. The diagnostic HBsAg-specific RIA provided a convenient assay with high sensitivity and low background. Since cell lysis was not required, in contrast to enzymatic tests, the transfected cells could be analyzed for gene expression of the endogenous viral genome.

The studies reported here focus on early events in the lytic cycle of EBV. In cell culture most of the EBV-transformed B lymphocytes carry the EBV genome in a latent status. However, via distinct pathways of stimulation including activation of viral immediate early promoters, these cells enter the lytic cycle leading to the synthesis of virus particles (in vitro forced by chemical inducers or by lytic superinfection). This cycle consists of a strongly regulated follow-up of various groups of viral genes, starting with trans-acting immediate early proteins. Here we show the possibility of applying the HBsAg system for analyses of these regulatory aspects.

\section{MATERIALS AND METHODS}

\section{(a) Sequences and promoter screening}

The B95-8 sequence of EBV (Baer et al., 1984) was analyzed by the UWGCG (Madison, WI) 'find' program for TATA-box consensus sequences (Corden et al., 1980). Convenient restriction sites located between the first methionine of the EBV ORFs $B M L F 1, B Z L F 1, B R L F 1, B I^{\prime} L F 4, B A L F 2$ and $B N L F 1$ (Farrell et al., 1987) and the cap sites of transcripts were used to insert the EBV promoters upstream from the reporter genes. The 5 '-ends of the control regions were selected considering two aspects: first, the constructions should not contain any additional TATA boxes; secondly, consensus sequences for binding sites of cellular factors, e.g. AP-1 (Angel et al., 1987; Lee et al., 1987) located in upstream sequences should be included.

\section{(b) Construction and purification of plasmids}

The standard plasmids and EBV promoter constructions were generated as shown in Figs. 1 and 2, and transformed in appropriate Escherichia coli strains. Transformants were grown in LB medium containing $50 \mu \mathrm{g} \mathrm{Ap} / \mathrm{ml}$. Plasmid preparations were carried out by the alkaline lysis procedure described by Maniatis et al. (1982). The purification from RNA and bacterial DNA was achieved by RNase A digestion $(50 \mu \mathrm{g} / \mathrm{ml})$ and high pressure liquid chromatography (Pharmacia-LKB). DNA concentrations were calculated according to the absorbance at $257 \mathrm{~nm}$.

\section{(c) Cell culture, transfection, chemical induction and superinfection}

The EBV-positive non-producer Raji line was grown in RPMI 1640 medium supplemented with $10 \%$ heat-inactivated foetal calf serum, 100 units $/ \mathrm{ml}$ of penicillin and $250 \mu \mathrm{g} / \mathrm{ml} \mathrm{of} \mathrm{streptomycin,} \mathrm{at} 37^{\circ} \mathrm{C}$. Transfections were performed by a modification of the technique of McCutchan and Pagano (1968). Raji cells were split $15 \mathrm{~h}$ before transfection. $10^{7}$ cells were transfected with $6 \mu \mathrm{g}$ of total DNA in $600 \mu \mathrm{l}$ transfection volume ( $\mathrm{pH} 7.4)$ at a dextran concentration of $0.5 \mathrm{mg} / \mathrm{ml}$. The cells were incubated for $45 \mathrm{~min}$ at room temperature under gentle movement. Then the dextran was washed out with Tris-buffered saline and the cells were cultured in $5 \mathrm{ml}$ of fresh medium.

For the induction of the lytic cycle Raji cells were either induced chemically or superinfected with P3HR-1 virus (Bayliss and Wolf, 1981). Chemical 
induction was achieved by addition of $40 \mathrm{mM}$ TPA and $3 \mathrm{mM} \cdot \mathrm{Na}$-butyrate to the culture medium after transfection. For superinfection, virus pelleted from $50 \mathrm{ml}$ P3HR-1 culture supernatant was used per $10^{6}$ Raji cells. The virus was prepared from the P3HR-1 culture supernatant (induced by TPA/butyrate for 10 days) by centrifugation for $2 \mathrm{~h}$ at $20000 \times g$. The superinfection assay $\left(10^{6}\right.$ cells per $\left.0.5 \mathrm{ml}\right)$ was incubated for $1 \mathrm{~h}$ at room temperature under gentle movement before the cells were transferred into fresh medium.

\section{RESULTS AND DISCUSSION}

\section{(a) Construction of reporter plasmids}

The sequences encoding $\mathrm{HBsAg}$ or CAT were used as reporter genes for various promoters (Figs. 1 and 2). Both genes were brought under the control of the SV40 carly promoter/cnhancer for comparing the reporter systems. In all promoter constructions the transcription start point (cap site) was cloned in original position to its promoter, whereas the trans-
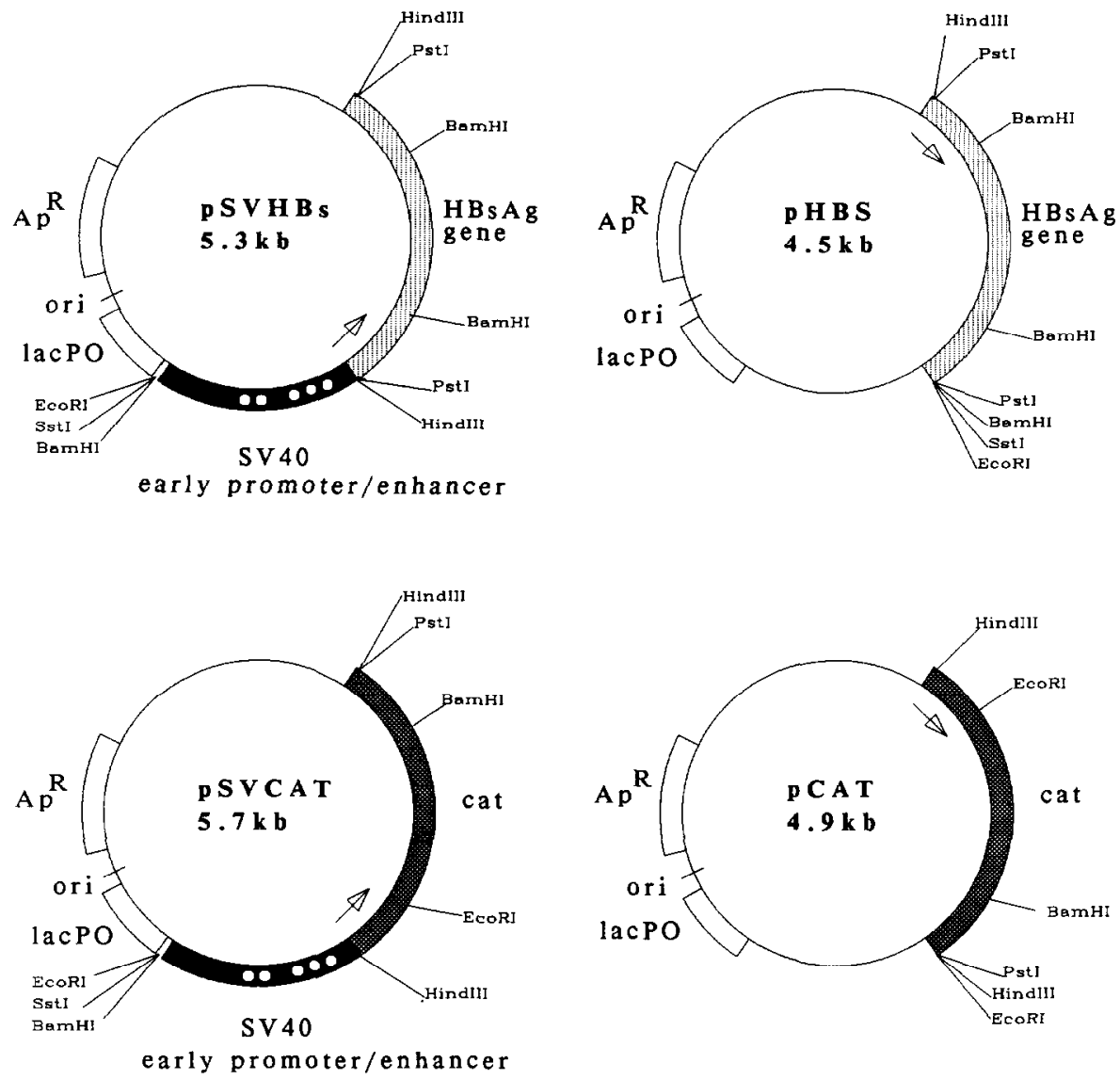

Fig. 1. Reporter gene constructs. The coding sequence of HBsAg was derived from HBV subtype AYW DNA by the use of XhoI (position 131 ) and BglII sites (position 1986) (Galibert et al., 1979). The ends of this 1855-bp fragment were converted to BglII (5'-end) and $S a l l$ sites ( $3^{\prime}$-end), respectively, to generate pAvBII, which was obtained from Albrecht von Brunn, ZMBH, Heidelberg. The BglII-SalI fragment containing a 25-bp $5^{\prime}$-untranslated sequence followed by the ATG start codon of the HBsAg-encoding gene (lacking pre-S sequences) was subcloned using modified pUC vector polylinkers. The cat and SV40 promoter sequences (72-bp and 21-bp repeats are indicated by white dots) were subcloned from the original pSV2CAT construction (Gorman et al., 1982). TaqI and PstI sites were used to construct pSVCAT in pUC18 vector (AccI-Pst I). For negative control (pCAT) the 2.2-kb HindIII cat fragment was inserted into pUC18 vector in negative orientation. For the construction of pSVHBs the coding sequence of HBsAg was excised from pHBs (PstI-HindIII) and cloned downstream the SV40 promoter/enhancer in exchange for the cat gene in pSVCAT. All promoter test constructions were cloned in pUC vectors. The orientation of the reporter genes is shown by arrows. 
lation start codon (first methionine of the ORF) was replaced by the start codon of the reporter gene. Constructions without viral promoter were used as negative control (reporter genes were cloned in negative orientation with respect to the bacterial lacPO) (Fig. 1).

EBV promoters belonging to different functional classes were selected considering regulatory aspects (Fig. 2). Positive and negative transcriptional control of immediate early genes (BZLFI, BMLF1, $B R L F 1, B I^{\prime} L F 4$ ) (Chevallier-Greco et al., 1986; Lieberman et al., 1986; Seibl et al., 1986; Biggin et al., 1987; Countryman et al., 1987; Seibl et al., 1987; Hardwick et al., 1988; Leser et al., 1989; Marschall et al., 1989) was of main interest regarding possible virus/cell interactions. Promoter activity of the early gene $B A L F 2$ (pl38) (Hatfull et al., 1988) and the latent membrane protein $B N L F 1$ (LMP) (Modrow and Wolf, 1986) was examined in comparison to immediate early gene regulation.

\section{(b) Hepatitis B virus surface antigen synthesis in transfected cells}

The EBV-positive non-producer B-cell line Raji was used for transfection assays. HBsAg production was shown $1-5 \mathrm{dpt}$ (pSVHBs) by indirect immuno- fluorescence, using a monoclonal antibody which recognized conformational epitopes of domain $A$ of the surface antigen (Fig. 3,II.). Recombinant HBsAg particles were demonstrated as granulous cytoplasmic structures. No background was seen in cells transfected with negative control plasmid pHBs (see Fig. 1).

In parallel experiments, $\mathrm{HBs} A \mathrm{~g}$ production and secretion could be monitored by RIA (Fig. 3,I.). A kinetic study of supernatant samples from 1 until $7 \mathrm{dpt}$ (pSVHBs) (see Fig. 1) demonstrated the steady increase of high-level production of $\mathrm{HBsAg}$ in Raji cells, promoted by the $S V 40$ early control region, leading to an accumulation of the reporter protein in the supernatant.

\section{(c) Comparison of reporter systems}

HBsAg production after transfection with pSVHBs could be shown in Raji cells by RIA using cell extracts, as well as culture supernatant (Fig. 4). Two days post-transfection the cell extracts contained optimal HBsAg concentrations, whereas four dpt the accumulation of secreted HBsAg resulted in even stronger RIA signals in samples of the supernatant.

Transfection with pSVHBs led to basal expres-

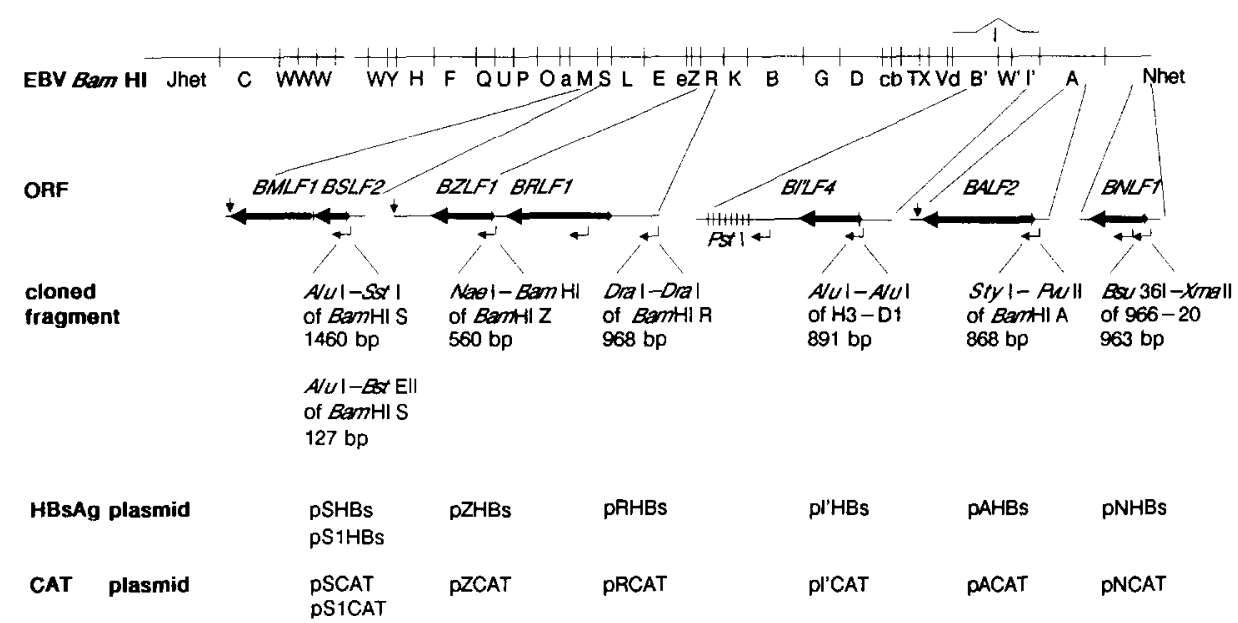

Fig. 2. Cloning of EBV promoter elements. The EBV standard genome is shown in its linearized form, subdivided into Bam HI fragments. Regulatory ORFs are presented in an enlarged drawing (boldface arrows). The corresponding promoter elements (bent horizontal arrows) were cloned into cat and $\mathrm{HBsAg}$ constructions, as described in Fig. 1 (vertical arrows show polyadenylation signals; the EBV Pst I repeats are indicated by repeated vertical lines). EBV DNA was derived from subclones of the B95-8 (Skare and Strominger, 1980) (Bam HI S, Bam HI Z, Bam HI R, BamHI A) or M-ABA strain (Polack et al., 1984)(H3-D1, 922-20). The promoter elements were excised using restriction sites as indicated and subcloned into pUC-derived vectors. The original EBV DNA restriction sites were either directly used for insertion into pUC polylinker sites or filled-in by PolIk for blunt end ligation with HincII-digested pUC vector. Subsequently the EBV promoter sequences were inserted in pHBs (Sst I-Pst I) or in pSVCAT where the SV40 sequence had been removed (SstI-HindIII). 


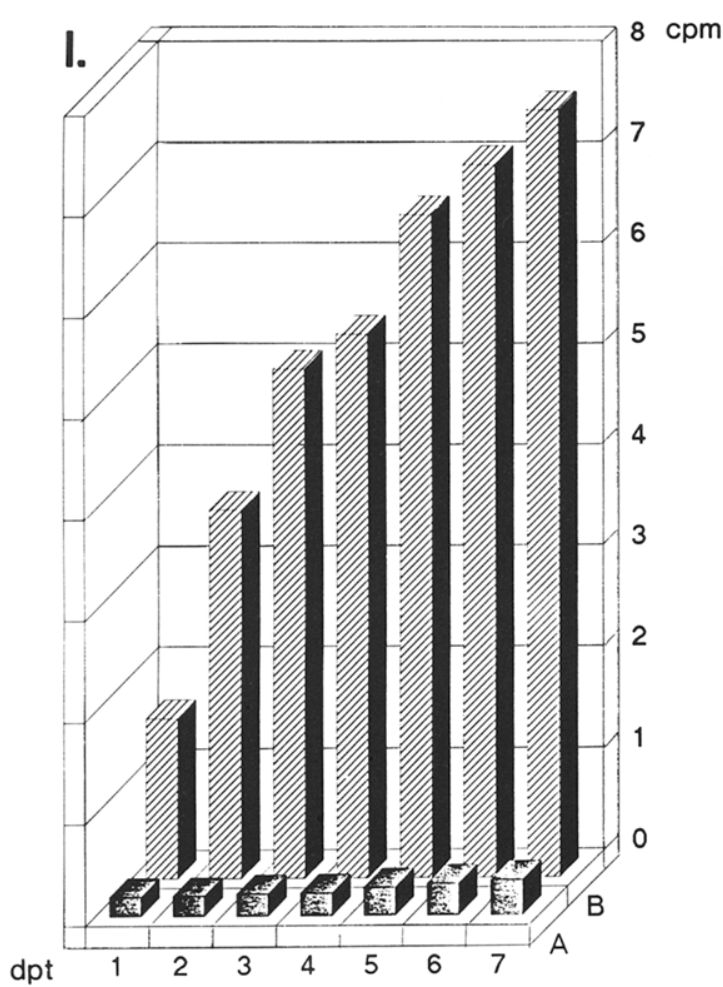

II.
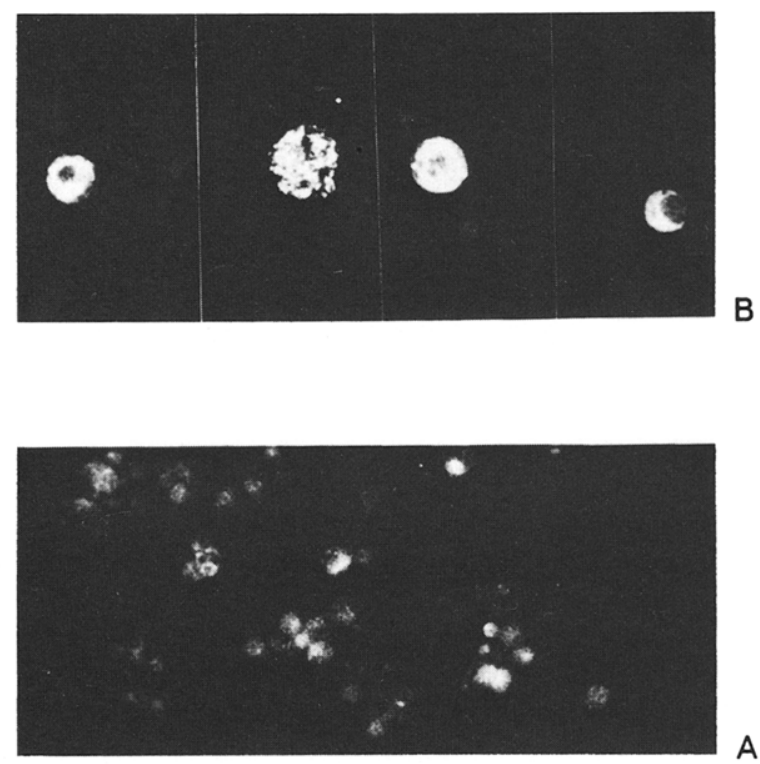

Fig. 3. HBsAg-specific RIA (I.) and immunofluorescence (II.). Raji cells were transfected with pHBs (I.A, II.A) and pSVHBs (I.B, II.B). The SV40 early control element was stimulated by TPA induction. HBsAg production was assayed by the routine diagnostic RIA for HBsAg (Abbott). $0.5 \mathrm{ml}$ of culture supernatant was incubated with solid-phase-conjugated anti-HBsAg antibodies overnight at room temperature. After washing, the secondary antibody ( ${ }^{125} \mathrm{I}$-labelled anti-HBsAg antibody, Abbott) was incubated at $42^{\circ} \mathrm{C}$ for $1 \mathrm{~h}$. Specific binding of radioactively labelled antibodies was measured in a gamma-scintillator (cpm values $\times 10^{3}$ ). For indirect immunofluorescence, transfected cells were cultured in Falcon Multiwell plates (six chambers, each containing $10^{7}$ cells in 5 ml medium). Samples were centrifuged at 1-5 dpt, washed in PBS and the cells were fixed on glass slides in ice-cold acetone for 5 min. After air drying, slides were stored at $-20^{\circ} \mathrm{C}$. Monoclonal antibodies against $\mathrm{HBsAg}\left(\mathrm{H} 35\right.$, Abbott) were diluted $1: 100$ in PBS and incubated for $2 \mathrm{~h}$ at $37^{\circ} \mathrm{C}$. After washing, the cells were incubated with a 1:100 dilution of fluorescein isothiocyanate-linked goat anti-mouse antibody (Medac) for $1 \mathrm{~h}$ followed by a final rinse in PBS. Note the granulous, cytoplasmic localization of HBsAg in the transfected cells and the steady accumulation in the supernatant with low background of the controls.

sion due to the SV40 early promoter/enhancer, which could be stimulated by TPA induction. Enhancement of $\mathrm{HBsAg}$ production was also achieved by cotransfection with the EBV factor $B M L F 1$, which was originally described as a promiscuous trans-activator (Lieberman et al., 1986). An expression vector for $B M L F 1$ (including the short $B S L F 2$ exon that is spliced to the $5^{\prime}$-end of $B M L F 1$ ) was kindly provided by A. Sergeant, Lyon (pSVSM; Chevallier-Greco et al., 1986).

These results were reproduced by parallel transfection assays with pSVCAT (analogous to pSVHBs). pCAT, containing no promoter sequences, was used as a negative control. TPA induction and trans-activation by the $B M L F 1$ protein led to highly elevated CAT activity in extracts from Raji cells transfected with pSVCAT, confirming the corresponding data of the $\mathrm{HBsAg}$ reporter system. No difference was noted between cell extracts prepared 2 or $4 \mathrm{dpt}$ (data not shown).

\section{(d) Analysis of the Epstein-Barr virus promoters}

EBV promoters belonging to several regulatory classes were tested for their activity under a variety of conditions (Fig. 5). The control regions of $B Z L F 1$, $B M L F I$ and $B I^{\prime} L F 4$ (immediate early group) were shown to be switched on in Raji cells, in which latency was disrupted. The reporter gene construction $\mathrm{pS} 1 \mathrm{HBs}$ contains the promoter region of the spliced $B S L F 1 / B M L S 1$ gene in a minimal version of 127 bp (Fig. 2). An AP-1 binding consensus se- 


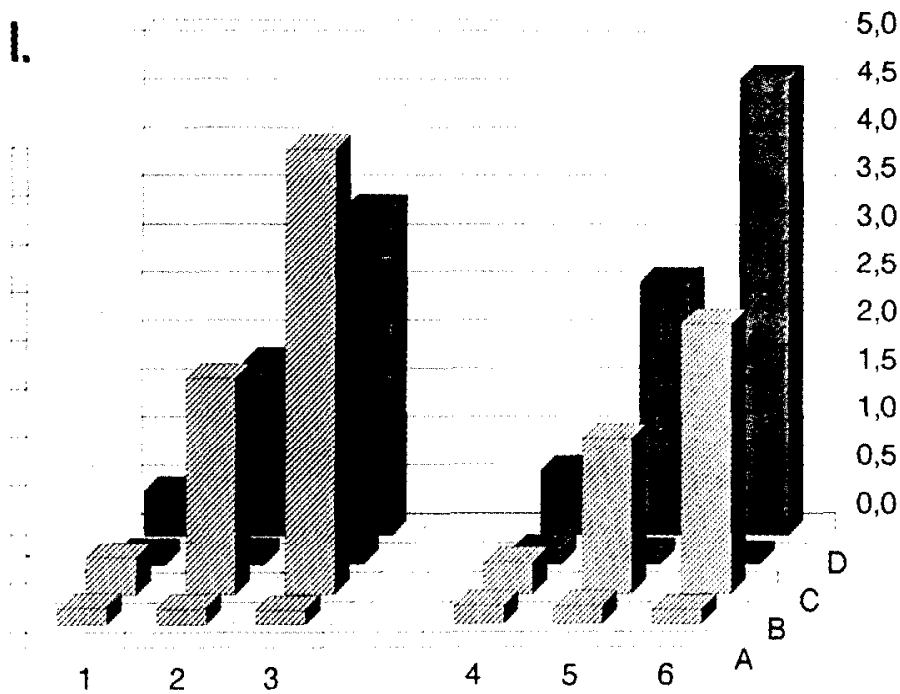

$5,0 \mathrm{cpm} \|$.

4,0

3,5

3,0

2,5

2,0

1,5

1,0

0,5

0,0
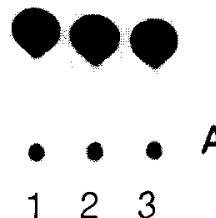

123
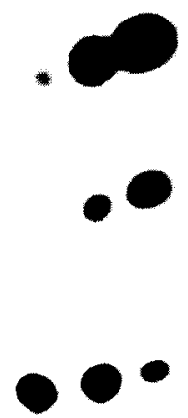

B

123

Fig. 4. Comparison of SV40 promoter activities measured by HBsAg reporter system (I.) (see legend to Fig. 3) and CAT assay (II.). Raji cells were transfected with SV40 promoter standard constructs (see Fig. 1) (pSVHBs and pSVCAT; B and D) or negative control constructions lacking SV40 promoter sequences (pHBs and pCAT; A and C). The reporter production under different conditions was measured from cell extracts ( $A$ and $B$ ), as well as from culture supernatant ( $C$ and D). Raji cells ( 1 and 4), Raji cells cotransfected with a $B M L F I$ expression vector ( 2 and 5) and Raji cells induced by TPA/butyrate $(3$ and 6$)$ were used $2 \mathrm{dpt}(1,2,3)$ and $4 \mathrm{dpt}(4,5,6)$. The CAT assays were performed as described by Gorman et al. (1982). Two days posttransfection the cells were centrifuged, washed in PBS and lysed by sonication on ice ( $100 \mu \mathrm{l}$ of $0.25 \mathrm{M}$ Tris $\cdot \mathrm{HCl} \mathrm{pH} \mathrm{8.0)}$. Cell debris was removed by centrifugation for $5 \mathrm{~min}$ at $500 \times g$. The protein concentrations were equilibrated after measurement of the optical densities at 260 and $280 \mathrm{~nm}$. $50 \mu \mathrm{l}$ of the protein extract was mixed with a reaction mixture containing $100 \mu \mathrm{l}$ of $0.25 \mathrm{M}$ Tris $\cdot \mathrm{HCl} \mathrm{pH} 8.0 / 20 \mu \mathrm{l}$ of $4 \mathrm{mM}$ acetyl coenzyme A (PharmaciaLKB $) / 10 \mu \mathrm{l}$ of ${ }^{14} \mathrm{C} \mathrm{Cm}(0.25 \mu \mathrm{Ci}$, Amersham $)$ and incubated for $1 \mathrm{~h}$ at $37^{\circ} \mathrm{C}$. $\mathrm{Cm}$ and its acetylated products were extracted with $400 \mu \mathrm{l}$ of ethyl acetate and evaporated in a speed-vacuum centrifuge. Dried samples were suspended in $10 \mu 1$ of ethyl acetate, spotted on silica gel thin-layer chromatography plates (Merck 5737) in chloroform/methanol (95:5) solvent. The plates were exposed against hyperfilm$\beta \max$ (Amersham) for 12 to $24 \mathrm{~h}$.

quence (Angel et al., 1987) is included, located $80 \mathrm{bp}$ upstream from the TATA box (Corden et al., 1980). Furthermore, a CAAT motif (Efstratiadis et al., 1980) was noticed 50 bp from the TATA box. In Raji cells $\mathrm{pS} 1 \mathrm{HBs}$ was found to be inactive during latency. Chemical induction by TPA/butyrate or superinfection with the lytic EBV strain P3HR-1 (immediately following the dextran transfection) led to the activation of $\mathrm{pS} 1 \mathrm{HBs}$, resulting in a steady increase of HBsAg in the supernatant until $5 \mathrm{dpt}$. As Raji cells contain about 50 copies of a defective EB viral genome (Hatfull et al., 1988), chemical induction led to the synthesis of the authentic EBV proteins. Therefore, as additional control, extracts of the transfected cells were tested on Western blots for the presence of EBV-specific proteins (Fig. 5B). Using $B M L F 1$-specific serum, proteins were demonstrated in induced and superinfected Raji cells. Activation of the latent Raji EBV genome is correlated with the synthesis of a prominent $60-\mathrm{kDa}$ protein encoded by
$B M L F 1 / B S L F 2$, including additional modified polypeptides, as described earlier (Marschall et al., 1989).

The promoters of $B Z L F 1$ and $B I^{\prime} L F 4$ were activated in latently infected Raji cells after TPA/butyrate induction (Fig. 5C and D) via synthesis or activation of viral and cellular trans-activators. Cotransfection with an expression vector for $B M L F 1$ protein up-regulated several reporter gene constructs, confirming that $B M L F 1$ acts universally. Enhanced HBsAg production was measured in cotransfection assays with constructs containing the $B I^{\prime} L F 4$ promoter (Fig. 5E), the promoter of $B M L F 1$ itself (data not shown) and the SV40 early promoter/enhancer (Fig. 4, rows 2 and 5).

The promoter construction of $B N L F 1$ (pNHBs) showed activity when transfected in latent Raji cells (Fig. 5F). BNLFl transcription (first TATA box of the ORF), leading to the synthesis of the $B N L F 1$ membrane protein (LMP), is compatible with laten- 

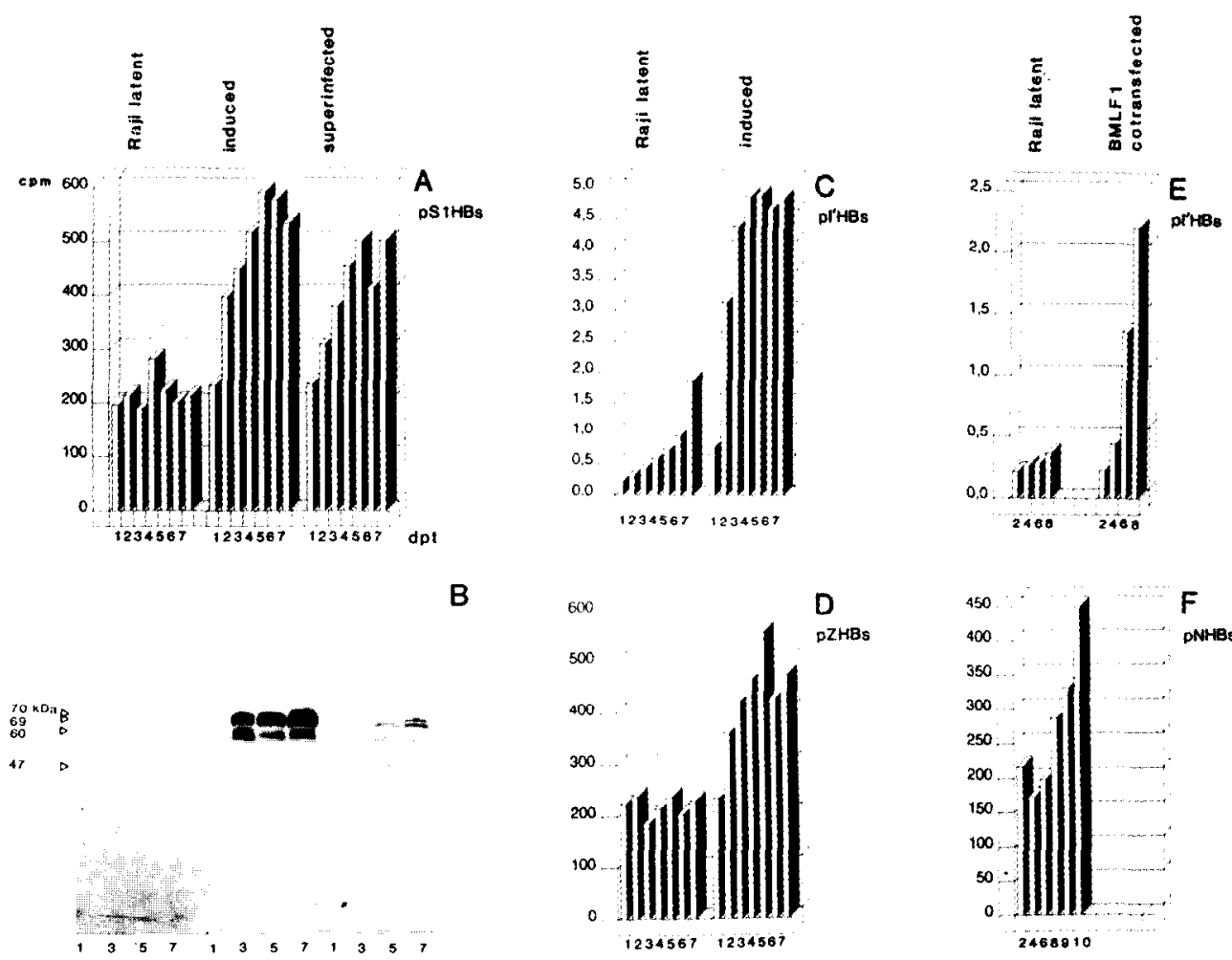

B
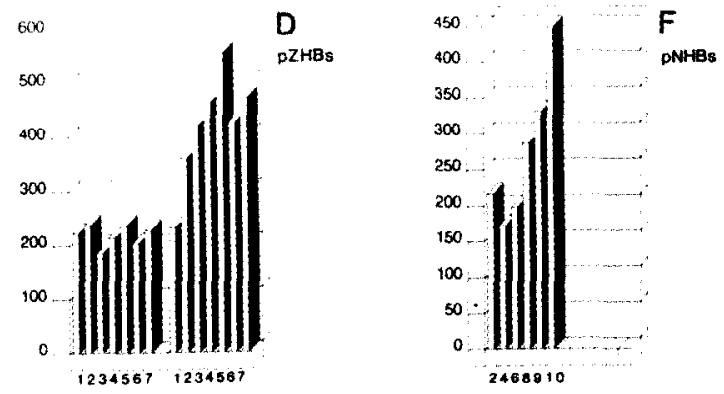

Fig. 5. EBV promoter activities in Raji cells. The kinetics of promoter activities were measured by the HBsAg reporter system (RIA, see legend to Fig. 3) from supernatant samples (A,C,D,E,F) and compared to specific proteins detected by Western blot (B) (days posttransfection indicated by numbers on bottoms). Raji cells wcrc transfected with promoter constructions corresponding to the EBV genes $B S L F 2 / B M L F 1$ (A), BI'LF4 (C,E), BZLF1 (D) and BNLFI (F) (see Fig. 2). The following conditions were created: transfection of latent Raji cells; transfection and subsequent induction by TPA/butyrate or superinfection with P3HR-1 virus; cotransfection with a $B M L F 1$ expression vector. As shown for $B M L F 1$, promoter activity (A) and protein production (B) were examined in parallel. $B M L F I$-specific proteins (major product $60 \mathrm{kDa}$ with modified species) were specified using a high-molecular-weight protein standard (Sigma) and are indicated by arrow heads. For Western blots, the cells were washed, lysed by sonication and the protein extracts wcre separated in $12.5 \%$ polyacrylamide gels $(0.1 \%$ SDS) and electrophoretically transferred onto nitrocellulose (BA 85 , Schleicher \& Schüll). EBV ORF-specific rabbit antisera were incubated overnight at room temperature in a 1:50 dilution. The blots were washed with TTBS and incubated for another $2 \mathrm{~h}$ at room temperature with peroxidase-conjugated antibodies against rabbit immunoglobulins (Dakopatts). After the final washing with TTBS, the blots were developed with $0.5 \mathrm{mg}$ of $3,3^{\prime}$-diaminobenzidine per $\mathrm{ml}$ and $0.01 \% \mathrm{H}_{2} \mathrm{O}_{2}$ in $50 \mathrm{mM}$ Tris (pH 7.6).

cy. In contrast to $B N L F 1$, no promoter activation of the $B A L F 2$ early gene (pAHBs) was detected in latent Raji cells (data not shown).

\section{(e) Conclusions}

For the evaluation of promoter activities we developed a new reporter system in which the reporter protein was detectable in the supernatant, taking advantage of the sensitive HBsAg RIA frequently used for diagnostic purposes. As our main interest was the regulation of EBV trans-acting genes, which are expressed in a strictly limited way and restricted in time, we needed to monitor the promoter activities over a certain time range under various growth conditions of different cell cultures (human B cell lines, human carcinoma cells, mouse fibroblasts).

(i) Using the HBsAg reporter system we were able to study the activity of selected control regions over ten days by RIA and indirect immunofluorescence.

(ii) As the reporter protein was secreted to the supernatant, the cell extracts remained available for additional tests, e.g., Western blots.

(iii) The results of the HBsAg reporter system were reproduced by experiments using the CAT assay system.

(iv) The use of test constructions with different 
viral promoters (SV40, EBV) showed that our new method could be employed universally.

(v) Control transfections of reporter constructs without promoter sequences proved that background expression remained at a low level.

EBV early and immediate early promoters were found to be down-regulated during latency and were activated by means of inducing the lytic expression in Raji cells, while the promoter of $B N L F 1$ (LMP) was shown to be active during the latent phase of infection. Using the HBsAg reporter system we could directly compare promoter activation and the start of protein synthesis of the corresponding gene encoded by the endogeneous EBV genome in Raji cells. The gene regulation of EBV was shown to occur on different levels, e.g., promoter activity (Chevallier-Greco et al., 1986), transcription efficiency and RNA transport (Schwarzmann et al., 1988; Leser et al., 1989), and translation and protein modification (Bayliss and Wolf, 1981; Marschall et al., 1989). We developed a sensitive method to detect low-grade changes of gene activation on the promoter level. The HBsAg reporter system provides a general method for monitoring control elements in the kinetics of transient expression assays.

\section{ACKNOWLEDGEMENTS}

This work was supported by grant Wo227/4 and Fa138/3-1 from the Deutsche Forschungsgemeinschaft. The authors are grateful to Christine Markert for collaboration in constructing the EBV LMP promoter construct and to Albrecht von Brunn for providing the HBV DNA subclone pAvBII.

\section{REFERENCES}

An, G., Hidaka, K. and Siminovitch, L.: Expression of bacterial $\beta$-galactosidase in animal cells. Mol. Cell. Biol. 2 (1982) $1628-1632$.

Angel, P., Baumann, I., Stein, B., Rahmsdorf, H.J. and Herrlich, P.: 12-O-Tetradecanoylphorbol-13-acetate induction of the human collagenase gene is mediated by an inducible enhancer element located in the 5 '-flanking region. Mol. Cell. Biol. 7 (1987) 2256-2266.

Baer, R., Bankier, A.T., Biggin, M.D., Deininger, P.L., Farrell, P.J., Gibson, T.J., Hatfull, G., Hudson, G.S., Satchwell, S.C.,
Seguin, C., Tuffnell, P.S. and Barrell, B.G.: DNA sequence and expression of the B95-8 Epstein-Barr virus genome. Nature 310 (1984) 207-211.

Bayliss, G.J. and Wolf, H.: The regulated expression of EpsteinBarr virus, III. Proteins specified by EBV during the lytic cycle. J. Gen. Virol. 56 (1981) 105-118.

Biggin, M., Bodescot, M., Perricaudet, M. and Farrell, P.: Epstein-Barr virus gene expression in P3HR1-superinfected Raji cells. J. Virol. 61 (1987) 3120-3132.

Chevallier-Greco, A., Manet, E., Chavrier, P., Mosnier, C., Daillie, J. and Sergeant, A.: Both Epstein-Barr virus (EBV)encoded trans-acting factors, EB1 and EB2, are required to activate transcription from an EBV early promoter. EMBO J. 5 (1986) 3243-3249.

Corden, J., Wasylyk, B., Buchwalder, A., Sassone-Corsi, P., Kedinger, C. and Chambon, P.: Promoter sequences of eucaryotic protein-coding genes. Science 209 (1980) 1406-1414.

Countryman, J., Jenson, H., Seibl, R., Wolf, H. and Miller, G.: Polymorphic proteins encoded within BZLF1 of defective and standard Epstein-Barr viruses disrupt latency. J. Virol. 12 (1987) 3672-3679.

deWet, J., Wood, K.V., DeLuca, M.R., Helinski, D.R. and Subramini, S.: Firefly luciferase gene: structure and expression in mammalian cells. Mol. Cell. Biol. 2 (1982) 1628-1632.

Efstratiadis, A.: The structure and evolution of the human $\beta$-globin gene family. Cell 21 (1980) 653-668.

Farrell, P.J.: Epstein-Barr virus (B95-8) strain. In O'Brian, S. (Ed.), Genetic Maps. Cold Spring Harbor Laboratory, Cold Spring Harbor, NY, 1987, pp. 99-107.

Galibert, F., Mandart, E., Fitoussi, F., Tiollais, P. and Charnay, P.: Nucleotide sequence of the hepatitis B virus genome (subtype AYW) cloned in E. coli. Nature 281 (1979) 646-650.

Gorman, C.M., Moffat, L.F. and Howard, B.H.: Recombinant genomes which express chloramphenicol acetyltransferase in mammalian cells. Mol. Cell. Biol. 2 (1982) 1044-1051.

Hardwick, J.M., Lieberman, P.M. and Hayward, S.D.: A new Epstein-Barr virus trans-activator, $R$, induces expression of a cytoplasmic early antigen. J. Virol. 62 (1988) 2274-2284.

Hatfull, G., Bankier, A.T., Barrell, B.G. and Farrell, P.J.: Sequence analysis of Epstein-Barr virus DNA. Virology 164 (1988) 334-340.

Lee, W., Mitchell, P. and Tjian, R.: Purified transcription factor AP-1 interacts with TPA-inducible enhancer elements. Cell 49 (1987) 741-752.

Leser, U., Schwarzmann, F., Marschall, M. and Wolf, H.: Transcription and protein expression pattern of EBV in freshly infected lymphoid cells. In Ablashi, D.V. (Ed.), Epstein-Barr Virus and Human Disease-II. The Humana Press, Clifton, NJ (1989) in press.

Lieberman, P., O'Hare, P., Hayward, G. and Hayward, D.: Promiscuous trans-activation of gene expression by an Epstein-Barr virus-encoded early nuclear protein. J. Virol. 60 (1986) 140-148.

Maniatis, T., Fritsch, E.F. and Sambrook, J.: Molecular Cloning. A Laboratory Manual. Cold Spring Harbor Laboratory, Cold Spring Harbor, NY, 1982.

Marschall, M., Leser, U., Seibl, R. and Wolf, H.: Identification 
of proteins encoded by Epstein-Barr viral trans-activator genes. J. Virol. 63 (1989) 938-942.

McCutchan, J.H. and Pagano, J.S.: Enhancement of the infectivity of simian virus $\mathbf{4 0}$ deoxyribonucleic acid with diethylaminoethyl-dextran. J. Nat. Cancer Inst. 41 (1968) 351-357.

Michel, M.L., Pontisso, P., Sobczak, E., Malpiece, Y., Streeck, R. and Tiollais, P.: Synthesis in animal cells of hepatitis B surface antigen particles carrying a receptor for polymerized human serum albumin. Proc. Natl. Acad. Sci. USA 81 (1984) 7708-7712.

Modrow, S. and Wolf, H.: Characterization of two related Epstein-Barr virus-encoded membrane proteins that are differentially expressed in Burkitt lymphoma and in vitro-transformed cell lines. Proc. Natl. Acad. Sci. USA 83 (1986) 5703-5707.

Polack, A., Hartl, G., Zimber, U., Freese, U.-K., Laux, G., Takaki, K., Hohn, B., Gissmann, L. and Bornkamm, G.W.: A complete set of overlapping cosmid clones of M-ABA virus derived from nasopharyngeal carcinoma and its similarity to other Epstein-Barr virus isolates. Gene 27 (1984) 279-288.
Schwarzmann, F.: Transkription von Epstein-Barr Virus in latent und lytisch infizierten Zellen. M.S. Thesis, Max von Pettenkofer-Institute, University of Munich, F.R.G., T988.

Seibl, R., Leser, U., Marschall, M., Modrow, S., Fuchs, K. and Wolf, H.: Identification and characterization of regulatory proteins of EBV. In Levine, P.H., Ablashi, D.V., Nonoyama, M., Pearson, G.R. and Glascr, R. (Eds.), Epstcin-Barr Virus and Human Disease. The Humana Press, Clifton, NJ, 1987, pp. 211-215.

Seibl, R., Motz, M. and Wolf, H.: Strain-specific transcription and translation of the Bam $\mathrm{HI} \mathrm{Z}$ area of Epstein-Barr virus. J. Virol. 60 (1986) 902-909.

Skare, J. and Strominger, J.L.: Cloning and mapping of Bam HI endonuclease fragments of DNA from the transforming B95-8 strain of Epstein-Barr virus. Proc. Natl. Acad. Sci. USA 77 (1980) 3860-3864.

Yoon, K., Thiede, M.A. and Rodan, G.A.: Alkaline phosphatase as a reporter enzyme. Gene 66 (1988) 11-17. 